\title{
If Transparency in Performance Measurement Becomes Mandatory: Towards Better Accountability?
}

\author{
Elisa Bonollo ${ }^{1}$ \\ ${ }^{1}$ Department of Economics and Business Studies, University of Genoa, Genoa, Italy \\ Correspondence: Elisa Bonollo, Department of Economics and Business Studies, University of Genoa, Genoa, \\ Italy. E-mail: bonollo@economia.unige.it
}

Received: April 15, 2018

doi:10.5539/ijbm.v13n7p58

\begin{abstract}
In most industrialized countries (including Italy), the increasing financial pressure on public organizations and the need for accountability have led to renewed attention on measuring public performance. In Italy, in 2009, the Legislative Decree 150 mandated all public organizations to introduce a 'performance management cycle' and publish a performance plan (a multi-year programming tool), a performance report (regarding the results obtained), and a document formalizing the model, the phases, and the timing of the adopted performance measurement system. This paper aims to understand whether transparency obligations in performance measurement correspond to a higher degree of accountability for stakeholders or whether they create greater bureaucracy. This study focuses on Italian public healthcare organizations since they need to be much more accountable towards their stakeholders on the results obtained in comparison to other public organizations. The empirical analysis conducted shows that the legal obligations for transparency in performance measurement are still important in a country with civil law like Italy— but they are not sufficient for improving accountability for stakeholders.
\end{abstract}

Keywords: accountability, healthcare organizations, performance measurement, transparency

\section{Introduction}

Over the past decades, many studies have investigated performance measurement in public organizations (Arnaboldi, Lapsley, \& Steccolini, 2015; Bouckaert \& Hallingan, 2008; Ittner \& Larcker, 1998; Johnsen, 2005; Modell, 2009; Rana, Hoque, \& Jacobs, 2018). In recent years in Italy, as in other countries, the increasing financial pressure on public organizations and the need for accountability have renewed attention on public performance measurement.

In 2009, lawmakers introduced a performance measurement system for all public organizations in Italy. This system requires public organizations to introduce a 'performance management cycle' with the aim to plan, control and report on performance. Furthermore, public organizations are required to publish online the documents introduced for planning and reporting performance.

This paper aims to understand whether transparency obligations on performance measurement correspond to a higher degree of accountability to stakeholders or whether they merely create more bureaucracy. In detail, this study focuses on Italian public healthcare organizations because, compared to other public organizations, they need to be much more accountable to their stakeholders on the results obtained with the resources used.

Content analysis is the method used for this investigation. The performance plans and performance reports over a time period of four years have been examined in order to understand whether they followed a mere compliance-based approach or if they were performance-oriented.

The paper is organized as follows. The second section looks into performance measurement and transparency in public organizations, with a special focus on public healthcare organizations. The third section describes the method used and the fourth section contains the empirical analysis conducted for this study. The fifth section presents final remarks.

\section{Performance Measurement and Transparency in Public Healthcare Organizations}

Since the new public management reform process (Hood, 1991; Pollitt \& Bouckaert, 2000), performance 
measurement in the public sector has led to renewed interest among both academic and managerial communities due to the need to support the decision-making process as well as to meet the accountability requirements. Specifically, the new public management reforms encouraged the adoption of result-oriented management and the development of new forms of accountability that progressively led to several countries introducing performance measurement systems based on 'advanced' approaches (Ball, Grubnic, \& Birchall, 2014; Behn, 2003; Bouckaert \& Halligan, 2008; Jansen, 2008; Van Helden, Johnsen, \& Vakkuri, 2008; Van de Walle, 2009; Yang \& Holzer, 2004).

In this regard, many performance measurement models have been developed across the years to not only consider the multiple dimensions of performance (Kaplan \& Norton, 1992; Epstein \& Manzoni, 1997), but also to highlight the connections between input, activities and outcome (Borgonovi, Anessi Pessina, \& Bianchi, 2018; Epstein \& Manzoni, 1997; Bititci, Nudurupati, Turner, \& Creighton, 1997) and the alignment between strategy and action (Anthony \& Govindarajan, 2001; Bryson, 2018; Neely, Gregory, \& Platts, 1995).

Over the past few years, among different types of public organizations, the most advanced forms of performance measurement have also become significant in the public healthcare sector. The huge amount of public resources invested (due to increased healthcare needs and the progress of technologies and research) and the high social impact of healthcare activities have highlighted the need to measure performance to support the decision making process, to develop a performance-based accountability and to satisfy the pressing request from citizens for more transparency.

As regards 'what' to measure, scholars distinguish between the depth (i.e. the levels) and the span (i.e. the dimensions) of performance (Behn, 2003).

As to the depth, referring to the Italian National Healthcare System, the central government sets the essential level of healthcare services that must be provided uniformly across the country and the 21 regional governments are responsible for organizing, financing, planning and controlling healthcare activities of 142 local healthcare organizations (LHOs). In each region, the LHOs provide healthcare services for the whole population in any given area, act partly as providers through their own personnel and facilities, and partly as purchasers of healthcare services from other public organizations or private providers. Also because of these different institutional levels, performance measurement can refer to the National Healthcare System (considering all the healthcare services provided in the national territory), the Regional Healthcare System (considering the activities of LHOs based in the regional territory), a single LHO and/or individual employees (medical or administrative staff).

With regard to the span that is the dimensions of performance to be measured, they may be classified into different categories, but are generally connected to the volume of activities carried out, resources used, effectiveness and efficiency levels, impacts on the community, and so on (Carbone et al., 2013; Le Pogam, Luangsay-Catelin, \& Notebaert, 2009).

This paper will specifically consider all the dimensions of performance measured at the LHO level.

Considering this latter level, in Italy, the need to measure public performance found 'new' answers in Legislative Decree no. 150/2009 and subsequent resolutions on implementation. This reform required all public organizations to implement the so-called 'performance management cycle', which consisted of the definition and the assignment of objectives to be achieved, the identification of the necessary resources, the monitoring of ongoing initiatives, the implementation of any corrective actions, the use of reward systems based on evaluation criteria, and finally the reporting of results. This cycle, as outlined in the decree, implies the construction of a logical map that defines the links between the institutional mandate, the mission, the strategic areas and objectives, the actions to be undertaken and the available or acquirable resources. In addition, organizations are required to publish on their institutional websites the documents formalizing the different steps of their performance management cycles: the 'performance measurement and assessment system', a methodological document that formalizes the model, steps and timing of the adopted performance measurement system; the 'performance plan', a multi-year planning document to be prepared annually; and the 'performance report', an annual report on the results obtained.

Specifically, the performance plan is a three-year planning document that outlines, consistently with the resources available, the objectives, the indicators and the targets to be used as references for the measurement, assessment and reporting of performance. This means that performance measurement does not stem from ministerial requirements, but rather refers to the objectives and the indicators defined by the organizations, and is conducted according to the criteria established by the above mentioned methodological document. 
Regarding the reporting of performance, the reform mandates the preparation of a document called 'performance report' to show the results obtained during the previous year as against the preset objectives and based on the resources available, also to acknowledge any gap and related causes and the consequent corrective measures to be implemented. The recipients of this report are policy-makers, top managers, external auditors, citizens and, more generally, all the parties involved. The performance report is meant to be a concise and easy-to-understand document accompanied by a number of annexes containing more detailed information.

As to the role of lawmakers, some authors specifically highlight how the culture of performance measurement and transparency cannot be introduced as a legal requirement. On the contrary, the development of new models and methodologies is more likely to occur in organizations that aim at continuous improvement on a voluntarily basis (Broad, Goddard, \& Von Alberti, 2007; Halachmi, 2005; Heinrich, 2007; Kuipers et al. McAdam \& Walzer, 2003). However, other authors point out that in countries ruled by civil law, including Italy, the juridical approach pushes the top managers of public organizations to wait for regulatory changes before innovating and start to change only when it becomes an obligation (legal requirement), particularly if (or only if) reinforced by penalties (Anselmi, 1995; Borgonovi, 2002; Hatry, 2002; Pollitt \& Bouckaert, 2000). Therefore, laws are an essential step towards the institutional validation of innovation. A regulation imposing the adoption of performance measurement in the healthcare sector may strongly encourage the LHOs to reinforce their planning and control functions and to pursue accountability and transparency.

Furthermore, the online accessibility of all the data and information regarding the activities planned and implemented by LHOs as promoted by the transparency requirement should help the LHOs to achieve a better level of accountability and give greater attention to the planning and reporting of their performance through an effort of selecting and ranking priorities.

On the other hand, apart from the opportunities mentioned above, there are also criticalities associated with performance transparency that have been highlighted in some studies. A broader information reporting, including the use of modern technologies, may sometimes make organizations more vulnerable to public criticism, thereby inducing managers to pay more attention to the appearance than to the substance of their actions. In addition, their operating capacity and productivity might be reduced due to an excessive amount of resources absorbed by performance measurement and reporting activities (Halachmi \& Greiling, 2013).

Furthermore, if transparency has been induced by a legislation-driven and top-down reform, this could be initially useful to overcome, or at least control, resistance to change and allow for a faster implementation of innovative solutions. However, if the innovation is subsequently not shared and its usefulness is not perceived, it may give rise to opportunistic behaviour accompanied with the risk that the innovation is implemented merely for complying with legal requirements (Anessi Pessina \& Steccolini, 2005; Jones \& Mussari, 2000). The latter case would be the umpteenth failure of the reform process, with bureaucratic and formal mechanisms prevailing over managerial principles and tools, which would have been therefore introduced only formally, without a specific purpose, to merely become a very expensive bureaucratic exercise.

In light of the theoretical framework and the legislation mentioned above, the remaining part of the paper will present the results of an empirical investigation considering the initial years of the reform implementation (2011-2014). The focus was on the analysis of the documents prepared by the Italian LHOs to highlight whether they are based on a managerial approach or are merely new tools used to express an old bureaucratic-formal approach.

\section{Methodology}

The methodology adopted was a content analysis that consisted of coding the text of the written documents into categories on the basis of selected criteria (Krippendorff, 1980; Weber, 1985). The purpose was to detect the type and the amount of information given in the documents with the assumption that the frequency of the reported information indicated the importance assigned to the identified categories.

The analysis was conducted from two perspectives: the structure of the documents and the nature of the information reported.

As to the document structure, the attention was on the scope and the amount of the information provided.

More specifically, based on the evidence of the literature review and on the analysis of a pre-sample of documents, information was subdivided for the performance plans into seven main information categories (IC): presentation, external context, identity, planned activity (indicators and targets to be achieved in terms of output, qualitative effectiveness, quantitative effectiveness, outcome, appropriateness, efficiency, economic and administrative performances), input (personnel, infrastructure and financing), process and improvement of the 
performance management cycle and others.

Conversely, seven different main ICs were identified for the performance reports: presentation, external context, mention of objectives, planned activities and expected targets, activity carried out and results obtained (indicators and targets achieved in terms of output, qualitative effectiveness, quantitative effectiveness, outcome, appropriateness, efficiency, economic and administrative performances), inputs used (personnel, infrastructure and financing), process and improvement of the performance management cycle and others.

The subsequent analysis of the nature of information was based on the assumption that, in order to plan and then to effectively report on the activities carried out and the results obtained, one has to use a balanced amount of quantitative (data, balance sheet items and indicators) and qualitative information, as well as tables (Gray, Dey, Owen, Evans, \& Zadek, 1997). In order to illustrate the nature of the information, some categories have been broken down into descriptive and quantitative information.

As far as coding and measuring units are concerned, this content analysis considered a 'sentence' as the coding unit in order to better understand the message (Milne \& Adler, 1999), and a 'line' as the measuring unit to quantify the space devoted to each individual information category (Patten, 2002). Even if words, sentences, proportion of pages and page size data were very common as measuring units, a line count measure was chosen so as to balance the time consumption, reliability and significance of the analysis conducted on Italian pdf file documents. This approach reports length by looking at lines of each IC relative to the total number of lines in the documents considered. This is an improvement over the absolute number of each IC line, since it better shows the importance of each IC for every LHO. As to the tables, considering their variety of forms and sizes, a separate content analysis was conducted by adopting the paragraph within the cell as the coding unit and words as the measuring units. The analysis did not include the table of contents, graphs, images, footnotes and the glossary. The so-called dominance principle was applied to conduct the analysis, which was done by a single coder (the author of this article) without using any software.

The online search was conducted in April 2014. For sample definition, only the performance plans with the corresponding performance reports were considered. Indeed, the purpose of the analysis was not only to know the contents of these documents, but also to verify whether an underlying managerial approach could be seen in their construction, therefore highlighting any link between the plans and the reports in order to fulfil the requirement of accountability effectively and transparently. As a consequence, the actual sample on which the results of the research were based consisted of 16 performance plans and the 16 corresponding performance reports (Table 1). This is why only 16 LHOs prepared both the three-year planning document and the corresponding final reporting document. The dramatic reduction in the number of LHOs considered with respect to the initial population stresses how many of them did not publish online the performance plan or did not report on their respective performances, thus neglecting the requirements of accountability and transparency.

Table 1. Sample of the LHOs

\begin{tabular}{crcc}
\hline LHOs & Total inhabitants & Performance Plan & Performance Report \\
\hline 1 & 1575587 & $2012-2014$ & 2012 \\
2 & 1252346 & $2012-2014$ & 2012 \\
3 & 1141372 & $2012-2014$ & 2012 \\
4 & 1107652 & $2012-2014$ & 2012 \\
5 & 931270 & $2012-2014$ & 2012 \\
6 & 876705 & $2012-2014$ & 2012 \\
7 & 815292 & $2012-2014$ & 2012 \\
8 & 590050 & $2011-2013$ & 2011 \\
9 & 548210 & $2012-2014$ & 2012 \\
10 & 544230 & $2012-2014$ & 2012 \\
11 & 396852 & $2012-2014$ & 2012 \\
12 & 362061 & $2012-2014$ & 2012 \\
13 & 233344 & $2012-2014$ & 2012 \\
14 & 182709 & $2012-2014$ & 2012 \\
15 & 159979 & $2012-2014$ & 2012 \\
16 & 101551 & $2012-2014$ & 2012 \\
\hline
\end{tabular}




\section{Empirical Evidence and Discussion}

The analysis showed a great variety of structures in the documents examined. Furthermore, a wide use of tables was observed to describe the human, technological and financial resources available, as well as the objectives and targets (performance plan) and results (performance report). The use of this method to present contents may be due to the willingness to make the examined documents more understandable and fast to read, but could also be related to the nature and origin of the data, i.e. budgets and annual reports.

All this made the content analysis more complex because, as pointed out in the methodological section, the process was subdivided into two parts, one concerning the body of the text and the other concerning tables.

As can be seen in Table 2, the analysis of the performance plan texts shows that a large space has been devoted to the explanation of the purposes and the structure of the performance plan (IC: 'presentation'), as well to the steps of the performance management cycle (IC: 'process and improvement of the performance management cycle'), with an approximate average of $10.8 \%$ and $16.4 \%$, respectively.

Table 2. Text of performance plan: results per information category

\begin{tabular}{|c|c|c|c|c|c|c|c|c|c|c|c|c|c|c|}
\hline & \multirow[b]{2}{*}{ Presentation } & \multirow[b]{2}{*}{$\begin{array}{l}\text { External } \\
\text { Context }\end{array}$} & \multicolumn{2}{|c|}{ Identity } & \multicolumn{7}{|c|}{$\begin{array}{l}\text { Planned activity and results expected } \\
\text { (performance indicators and targets) }\end{array}$} & \multirow{2}{*}{$\begin{array}{c}\text { Input } \\
\text { (personnel, } \\
\text { infrastructure, } \\
\text { financing) }\end{array}$} & \multirow{2}{*}{$\begin{array}{l}\text { Process and } \\
\text { improvement } \\
\text { of the } \\
\text { performance } \\
\text { management } \\
\text { cycle }\end{array}$} & \multirow[b]{2}{*}{ Other } \\
\hline & & & $\begin{array}{l}\text { institutional } \\
\text { tasks, } \\
\text { organizational } \\
\text { structure }\end{array}$ & $\begin{array}{l}\text { Strategies } \\
\text { and } \\
\text { objectives }\end{array}$ & Output & $\begin{array}{l}\text { Qualitative } \\
\text { Effectiveness }\end{array}$ & $\begin{array}{l}\text { Quantitative } \\
\text { Effectiveness }\end{array}$ & Outcome & Appropriateness & Efficiency & $\begin{array}{l}\text { Economic and } \\
\text { administrative } \\
\text { performances }\end{array}$ & & & \\
\hline MEAN & $10.83 \%$ & $17.84 \%$ & $23.76 \%$ & $19.60 \%$ & $1.39 \%$ & $0.16 \%$ & $0.00 \%$ & $0.00 \%$ & $0.02 \%$ & $0.00 \%$ & $1.75 \%$ & $8.17 \%$ & $16.48 \%$ & $0.00 \%$ \\
\hline $\begin{array}{l}\text { MEDIAN } \\
\text { STANDARD }\end{array}$ & $9.29 \%$ & $14.72 \%$ & $24.03 \%$ & $12.41 \%$ & $0.00 \%$ & $0.00 \%$ & $0.00 \%$ & $0.00 \%$ & $0.00 \%$ & $0.00 \%$ & $0.00 \%$ & $5.97 \%$ & $13.47 \%$ & $0.00 \%$ \\
\hline
\end{tabular}

Referring to the contents of the 'presentation IC', most of the examined documents mentioned the need to implement the actions required by the national and regional legislations, thus once again confirming the importance of a regulation for the introduction of new management tools. In three cases, in addition to regulatory compliance, the performance plans were clearly prepared for other purposes as well, such as the enhancement of the information system and the dissemination of the culture of performance, while in only two cases, the defined document was also adopted for external purposes, in order to favour accountability.

Almost $44 \%$ of the information pertained to the 'identity IC', which described the institutional purposes, the mission, the areas of intervention and the organizational set-up of the LHOs, as well as the strategies and objectives defined by the managers. It comprised a very general part, often with extensive references to the national legislation. More specifically, the 'identity IC' mainly consisted of a definition of the mission and a description of the organizational set-up, while less than half of the measuring units were devoted to the strategies and objectives decided by the managers. The lesser significance of the latter type of information can be partly justified by the abundant space specifically devoted, in the tables of the performance plan (Table 3), to information on strategies and objectives (slightly less than 20\%) and to the relative 'performance indicators and targets' to be achieved (slightly more than 56\%). In the latter case, most of the used indicators pertained to the 'output' (average 31\% with 18.53\% standard deviation) that is the different types of activities planned and the projects to be implemented, as well as, in some cases, the volume or trend of the healthcare services to be delivered to the users. The significance of the 'output IC' was certainly linked to the greater availability of data and the need to share information on planned activities with all the LHO personnel, but also to the need to give the community proof of the type and amount of healthcare services to be provided through easy to understand indicators so as to reinforce their social legitimization.

In addition to the 'output IC', the parts of the table dedicated to planned activities also showed indicators and targets relative to economic performances and administrative services in support of the healthcare activity (IC: Economic and administrative performances), with an average of $12 \%$ (although with a very high variability). Particular importance was also given to administrative activities in terms of information flows to be supplied, plans to be prepared, reports to be written and submitted, payments to be made, and so on, which were measured with 'done/not done' type of indicators. This is a signal of a progressive bureaucratization and formalization of the activity. Conversely, as far as economic performance indicators and targets were concerned, the analysis revealed that one of the main objectives identified was cost reduction (particularly in the pharmaceutical area), with very few cases connecting this problem to the verification of the appropriateness of healthcare treatments 
(average of the appropriateness IC: over 1\%) and to the rationalization of the use of resources (average of the efficiency IC: near to zero).

The information dedicated to the economic, social, demographic and epidemiologic conditions of the population (IC: external context) on an average was $17.8 \%$ in the body of the text, and $13.3 \%$ in the tables, even though it showed a high variability. Generally, this was quantitative information to outline the framework under which the LHOs operated, but only in a few cases, the causal link with subsequently defined three-year strategies and objectives was defined.

Table 3. Tables of performance plan: results per information category

\begin{tabular}{|c|c|c|c|c|c|c|c|c|c|c|c|c|}
\hline & \multirow{2}{*}{$\begin{array}{l}\text { External } \\
\text { Context }\end{array}$} & \multirow{2}{*}{$\begin{array}{c}\text { Identity } \\
\text { Strategies } \\
\text { and } \\
\text { objectives }\end{array}$} & \multicolumn{7}{|c|}{$\begin{array}{l}\text { Planned activity and results expected } \\
\text { (performance indicators and targets) }\end{array}$} & \multirow{2}{*}{$\begin{array}{c}\text { Input } \\
\text { (personnel, } \\
\text { infrastructure, } \\
\text { financing) }\end{array}$} & \multirow{2}{*}{$\begin{array}{l}\text { Process and } \\
\text { improvement } \\
\text { of the } \\
\text { performance } \\
\text { management } \\
\text { cycle }\end{array}$} & \multirow{2}{*}{ Other } \\
\hline & & & Output & $\begin{array}{l}\text { Qualitative } \\
\text { Effectiveness }\end{array}$ & $\begin{array}{l}\text { Quantitative } \\
\text { Effectiveness }\end{array}$ & Outcome & Appropriateness & Efficiency & $\begin{array}{l}\text { Economic and } \\
\text { administrative } \\
\text { performances }\end{array}$ & & & \\
\hline$\overline{M E A N}$ & $13.35 \%$ & $19.85 \%$ & $30.99 \%$ & $4.26 \%$ & $5.53 \%$ & $1.68 \%$ & $1.62 \%$ & $0.13 \%$ & $12.12 \%$ & $8.40 \%$ & $2.08 \%$ & $0.00 \%$ \\
\hline $\begin{array}{l}\text { MEDIAN } \\
\text { STANDARD }\end{array}$ & $2.18 \%$ & $17.03 \%$ & $33.50 \%$ & $3.24 \%$ & $6.21 \%$ & $0.38 \%$ & $1.03 \%$ & $0.00 \%$ & $9.73 \%$ & $6.60 \%$ & $0.00 \%$ & $0.00 \%$ \\
\hline DEVIATION & $24.01 \%$ & $13.98 \%$ & $18.53 \%$ & $4.46 \%$ & $4.37 \%$ & $2.17 \%$ & $2.02 \%$ & $0.45 \%$ & $12.69 \%$ & $9.35 \%$ & $5.83 \%$ & $0.00 \%$ \\
\hline
\end{tabular}

Another feature shared by the examined documents was the attention devoted to the information on human resources compared to the information on available infrastructures. Referring to the 'input IC' $(8.17 \%$ in the body of the text and $8.40 \%$ in the tables, on average), almost all the information, both in the body of the text and in the tables, was concerned with the staff, categorised by gender, contract type and qualification, and the related training activities organized by the LHOs. The information on infrastructures merely pertained to the number of beds available in the different facilities (hospitals, hospices, health care residences for the elderly, etc.), while virtually nothing was specified as to the technologies and healthcare equipment available and the required investments. Moreover, the information concerning the types and the amounts of funds obtained by the LHOs was equally scarce.

Regarding the performance reports, the analysis of the content of the text showed the level of importance given to the presentation of the purposes and the structure of the document ('presentation IC') as well as of the various steps followed in the performance management cycle, concluding with the publication of the performance report itself ('process and improvement of the performance management cycle IC'), with an average, considering both ICs, of almost $32 \%$ (Table 4). Special attention was paid to the economic, social, demographic and epidemiologic conditions of the population ('external context IC') (about 13\% on average). However, most of the examined documents merely resumed the part already included in the performance plan and only a few documents described the criticalities highlighted in the context during the actual functioning of the LHOs, with the consequent failure to achieve specific objectives.

Table 4. Text of performance report: results per information category

\begin{tabular}{|c|c|c|c|c|c|c|c|c|c|c|c|c|c|}
\hline & \multirow[b]{2}{*}{ Presentation } & \multirow{2}{*}{$\begin{array}{l}\text { External } \\
\text { Context }\end{array}$} & \multirow{2}{*}{$\begin{array}{l}\text { Mention of } \\
\text { objectives, } \\
\text { planned } \\
\text { activities and } \\
\text { expected } \\
\text { targets }\end{array}$} & \multicolumn{7}{|c|}{$\begin{array}{l}\text { Activity carried out and results obtained } \\
\text { (performance indicators and targets) }\end{array}$} & \multirow{2}{*}{$\begin{array}{c}\text { Input } \\
\text { (personnel, } \\
\text { infrastructure, } \\
\text { financing) }\end{array}$} & \multirow{2}{*}{$\begin{array}{l}\text { Process and } \\
\text { improvement } \\
\quad \text { of the } \\
\text { performance } \\
\text { management } \\
\quad \text { cycle }\end{array}$} & \multirow[b]{2}{*}{ Other } \\
\hline & & & & Output & $\begin{array}{l}\text { Qualitative } \\
\text { Effectiveness }\end{array}$ & $\begin{array}{l}\text { Quantitative } \\
\text { Effectiveness }\end{array}$ & Outcome & Appropriateness & Efficiency & $\begin{array}{l}\text { Economic and } \\
\text { administrative } \\
\text { performances }\end{array}$ & & & \\
\hline MEAN & $22.35 \%$ & $12.87 \%$ & $8.40 \%$ & $21.38 \%$ & $0.43 \%$ & $0.39 \%$ & $0.11 \%$ & $0.23 \%$ & $0.06 \%$ & $7.01 \%$ & $9.07 \%$ & $8.90 \%$ & $2.55 \%$ \\
\hline $\begin{array}{l}\text { MEDIAN } \\
\text { STANDARD }\end{array}$ & $10.77 \%$ & $8.30 \%$ & $7.37 \%$ & $7.63 \%$ & $0.00 \%$ & $0.00 \%$ & $0.00 \%$ & $0.00 \%$ & $0.00 \%$ & $4.94 \%$ & $5.96 \%$ & $5.52 \%$ & $0.00 \%$ \\
\hline DEVIATION & $24.42 \%$ & $12.30 \%$ & $11.00 \%$ & $26.76 \%$ & $1.69 \%$ & $1.26 \%$ & $0.32 \%$ & $0.73 \%$ & $0.25 \%$ & $7.66 \%$ & $10.95 \%$ & $10.40 \%$ & $8.90 \%$ \\
\hline
\end{tabular}

Regarding the tables of the performance report (Table 5), the analysis observed that, except for two cases, the activities carried out and results obtained were always connected to the strategies and objectives, indicators and expected targets. This allowed stakeholders to immediately and easily compare the plans with the results. Precisely due to this correspondence with the planning part, most of the information on the activities carried out and results obtained by the LHOs were concerned with the 'output IC' in the performance report too, with the 
quantitative information slightly more than the qualitative information (on average, $15.59 \%$ and $12.85 \%$, respectively).

Also, the importance of the 'economic and administrative performances IC' stood out clearly, being generally supplemented with excerpts of the accounting documents reporting on the costs incurred and resources used, with a clear concern of the LHOs in reporting on the resources used and the economic sustainability of their activities.

Table 5. Tables of performance report: results per information category

\begin{tabular}{|c|c|c|c|c|c|c|c|c|c|c|c|c|}
\hline \multirow[b]{3}{*}{ MEAN } & \multirow{2}{*}{$\begin{array}{l}\text { External } \\
\text { Context }\end{array}$} & \multirow{2}{*}{$\begin{array}{l}\text { Mention of } \\
\text { objectives, } \\
\text { planned } \\
\text { ativities and } \\
\text { expected } \\
\text { targets }\end{array}$} & \multicolumn{7}{|c|}{$\begin{array}{l}\text { Activity carried out and results obtained } \\
\text { (performance indicators and targets) }\end{array}$} & \multirow{2}{*}{$\begin{array}{c}\text { Input } \\
\text { (personnel, } \\
\text { infrastructure, } \\
\text { financing) }\end{array}$} & \multirow{2}{*}{$\begin{array}{l}\text { Process and } \\
\text { improvement } \\
\text { of the } \\
\text { performance } \\
\text { management } \\
\text { cycle }\end{array}$} & \multirow{2}{*}{ Other } \\
\hline & & & Output & $\begin{array}{l}\text { Qualitative } \\
\text { Effectiveness }\end{array}$ & $\begin{array}{l}\text { Quantitative } \\
\text { Effectiveness }\end{array}$ & Outcome & Appropriateness & Efficiency & $\begin{array}{l}\text { Economic and } \\
\text { administrative } \\
\text { performances }\end{array}$ & & & \\
\hline & $2.76 \%$ & $36.67 \%$ & $28.44 \%$ & $3.01 \%$ & $3.16 \%$ & $2.11 \%$ & $1.19 \%$ & $0.45 \%$ & $16.38 \%$ & $4.84 \%$ & $0.21 \%$ & $0.79 \%$ \\
\hline MEDIAN & $0.00 \%$ & $29.25 \%$ & $26.81 \%$ & $1.81 \%$ & $1.44 \%$ & $0.69 \%$ & $0.00 \%$ & $0.00 \%$ & $10.88 \%$ & $3.36 \%$ & $0.00 \%$ & $0.00 \%$ \\
\hline STANDARD & & & & & & & & & & & & \\
\hline DEVIATION & $4.81 \%$ & $27.40 \%$ & $20.78 \%$ & $3.28 \%$ & $4.15 \%$ & $4.03 \%$ & $2.62 \%$ & $1.81 \%$ & $21.69 \%$ & $5.37 \%$ & $0.84 \%$ & $2.90 \%$ \\
\hline
\end{tabular}

As to the other ICs regarding the activities carried out and the results obtained, those concerning results expressed in terms of qualitative and quantitative effectiveness, the outcome, appropriateness and efficiency were very poor, with the sole exception of some documents in which the qualitative and quantitative effectiveness played a rather significant role in terms of information on mobility from/to other LHOs, waiting lists, screening and prevention activities.

Furthermore, the review of performance reports revealed that in almost all cases, there was the substantial lack of a part concerning the analysis of the degree of achievement of targets. In general, there was no analysis of the criticalities that may have led to disappointing performances. This could reduce the performance report into a mere reporting document with no impact on subsequent planning activities. In this regard, however, this gap may be justified by the fact that, in most cases, the preset objectives and the targets seem to have been achieved with very high percentages (often nearly 100\%). This fact, though, could indicate the existence of another problem: the consideration that the said objectives were defined with excessive caution, while the more challenging objectives and targets could be better identified for the future.

Regarding the nature of the information, for all the ICs of performance plans and performance reports, except for those pertaining to the 'presentation', 'process' and 'other' ICs, the coding units were distinguished in connection with how the information was expressed: either in quantitative (when the coding units presented a number) or qualitative terms (in the opposite cases).

The analysis revealed that the weight of the descriptive information was usually lower than that of the quantitative information.

However, it is significant to observe how the ICs concerning the indicators and the targets were essentially descriptive in the performance plans and quantitative in the performance reports, presumably due to a difficulty or a lack of interest in defining the objectives to be achieved with a number. On the contrary, we should appreciate the effort of those LHOs that incorporated both qualitative and quantitative information in their performance reports with the intention to provide their internal as well as external stakeholders with a more objective knowledge base for assessing their performances.

In summary, despite the small sample size of examined documents and also considering the well-known limitations of the use of content analysis (Milne \& Adler, 1999; Unerman, 2000), we may draw some considerations:

- The LHOs' efforts in defining and reporting the strategies, objectives, indicators and the targets to be achieved with the resources available is certainly appreciable. However, the definition of strategies and objectives, preceded by a description of their context, often lacks a definition of the causal link existing between the starting situation of an LHO and its strategic choices, thus depriving its stakeholders of the possibility to understand the LHO's willing contribution in improving the pre-existing health conditions of the population.

- The performance identified by the LHO generally refers to the type and volume of the activity to be carried 
out, with a substantial lack of the categories of effectiveness, efficiency, outcome and appropriateness of the healthcare services.

- We observed a certain attention to the economic performance to be achieved and to the support administrative services to be delivered, justified with the pressure LHOs constantly face to reduce costs and promptly and exhaustively submit to the regional government the information flows required to govern the Regional Healthcare System.

- The objectives, indicators and targets to be achieved are, in most cases, of a qualitative nature, with a consequent higher degree of ambiguity and discretionary power that inevitably affect the level of accountability towards the stakeholders.

- The focus of the annual performance reports is on the results obtained in terms of the type and volume of services delivered and costs, with virtually no attention given to the other dimensions (effectiveness, efficiency, outcome and appropriateness).

- The poor attention devoted to the analysis of deviations between plans and reports reflects the risk of leading to a substantial lack of impact of measurements on future planning, ending up by limiting the potential of the introduced innovation.

\section{Conclusion}

To face the shrinkage of public resources allocated to the healthcare sector without reducing the quantity and quality of the services provided, it is essential for public LHOs to measure and control their performances, and report on the results for all their stakeholders.

This is the background against which a growing interest in performance measurement and transparency has been observed over the years among lawmakers, scholars and LHOs.

In 2009, the Italian national lawmaker introduced an obligation for public healthcare organizations to adopt the performance management cycle and consequently prepare and publish a multi-year planning document (performance plan), an annual report (performance report) and a methodological document on their institutional websites.

This paper, which reported on the results of an investigation conducted on the documents published by Italian LHOs in the initial years of the reform implementation, was developed to examine whether the legal obligation led to the dissemination of documents capable of fulfilling the performance-based accountability needs or if it was reduced to just another legal formality.

The documents analysed by using content analysis showed differences in their structures and volume of information reported, but all shared a focus on the measurement of the output in terms of the type and volume of the healthcare services to be delivered (performance plan) or delivered in the previous year (performance report). A certain attention was devoted to the economic performance and the administrative support services, a proof of the importance of the economic sustainability of the healthcare services offered and to the work of non-medical staff. On the other hand, while the information provided on effectiveness, efficiency, appropriateness and outcome of healthcare services was definitely scarce, the information on the context in which the LHOs operated was conversely abundant, although often with no causal connection with the part concerning the definition of the strategies and objectives to be achieved (in terms of the initial situation to be improved) or with the part regarding the reporting of the results obtained (in terms of the criticalities and opportunities encountered by the LHOs during their actual operations).

In conclusion, the legal obligation to measure performances and ensure transparency has not been proven to suffice to ensure greater accountability to the stakeholders by the LHOs in general. A strong commitment towards this purpose should be developed by the regional governments (who are the funders that govern the Regional Healthcare Systems), as well as a positive perception of the usefulness of the new tools, namely a positive relationship between the benefits and the costs involved in their introduction. Certainly, the LHOs that have complied with the requirements of the new legislation have improved their level of external accountability, because their performance plans and performance reports are often the sole non-accounting documents regarding planning and final reporting to be published online. However, there is much room for improvement if one wants to obtain the best from these documents in terms of balancing performance management needs with the requirement of accountability and transparency in view of creating the opportunity to receive a feedback from the community and identify the critical areas from the point of view of the services to be delivered or the information to be provided. 


\section{References}

Anessi, Pessina, E., \& Steccolini, I. (2005). Evolutions and limits of new public management-Inspired budgeting practices in Italian Local Government. Public Budgeting and Finance, 25(2), 1-14. https://doi.org/10.1111/j.0275-1100.2005.00358.x

Anselmi, L. (1995). Il processo di trasformazione della pubblica amministrazione. Torino: Giappichelli.

Anthony, R. N., \& Govindarajan, V. (2001). Management Control Systems. Boston, MA: McGraw-Hill.

Arnaboldi, M., Lapsley, I., \& Steccolini, I. (2015). Performance management in the public sector: the ultimate challenge. Financial Accountability and Management, 31(1), 1-22. https://doi.org/10.1111/faam.12049

Ball, A., Grubnic, S., \& Birchall, J. (2014). Sustainability accounting and accountability in the public sector. In J. Bebbington, J. Unerman, \& B. O’Dwyer (Eds.), Sustainability accounting and accountability (pp. 176-195). New York: Routledge.

Behn, R. D. (2003). Why measure performance? Different purposes require different measures. Public Administration Review, 63(5), 586-606. https://doi.org /10.1111/1540-6210.00322

Bititci, U. S., Nudurupati, S. S., Turner, T. J., \& Creighton, S. (2002). Web enabled performance measurement systems. International Journal of Operations and Production Management, 22, 1273-1287. https://doi.org/10.1108/01443570210450310

Borgonovi, E. (2002). Principi e sistemi aziendali per le pubbliche amministrazioni. Milano: Egea.

Borgonovi, E., Anessi Pessina, E., \& Bianchi, C. (2018). Outcome-Based Performance Management in the Public Sector. Berlin: Springer.

Bouckaert, G., \& Halligan, J. (2008). Managing Performance: International Comparisons. New York, NY: Routledge.

Broad, M., Goddard, A., \& Von Alberti, L. (2007). Performance, strategy and accounting in Local Government and Higher Education in the UK. Public Money and Management, 27(2), 119-126. https://doi.org/10.1111/j.1467-9302.2007.00567.x

Bryson, J. M. (2018). Strategic planning for public and nonprofit organizations. Hoboken, New Jersey: Wiley.

Carbone, C., Lecci, F., Lega, F., Predestini, A., Rotolo, A., Tarricone, R., \& Valotti, G. (2013). Misurare le performance per creare valore nelle aziende sanitarie pubbliche: uno strumento multidimensionale di valutazione. In Cergas, Rapporto OASI 2013 - Osservatorio sulle aziende e sul sistema sanitario italiano (pp. 515-550). Milano: Egea.

Epstein, M. J., Manzoni, J. F. (1997). The Balanced Scorecard and tableau de bord: translating strategy into action, Management Accounting, 79, 28-36.

Gray, R., Dey, C., Owen, D., Evans, R., \& Zadek, S. (1997). Struggling with the praxis of social accounting. Stakeholders, accountability, audits and procedures. Accounting, Auditing and Accountability Journal, 10(3), 325-364. https://doi.org/10.1108/09513579710178106

Halachmi, A. (2005), Performance measurement: test the water before you dive in. International Review of Administrative Sciences, 71(2), 255-266. https://doi.org/10.1177/0020852305053884

Halachmi, A., \& Greiling. D. (2013). Transparency, e-government and accountability. Public Performance Management Review, 36(4), 562-584. https://doi.org/10.2753/PMR1530-9576360404

Hatry, H. P. (2002). Performance measurement: fashion and fallacies. Public Performance and Management Review, 25(4), 352-358. http://www.jstor.org/stable/3381128

Heinrich, C. J. (2007). Measuring Public Sector Performance and Effectiveness. In B. G. Peters, \& J. Pierre (Eds), The handbook of public administration (pp. 32-49), London: Sage. http://dx.doi.org/10.4135/9780857020970.n3

Hood, C. (1991). A public management for all seasons?. Public Administration, 69, 3-19. https://doi.org/10.1111/j.1467-9299.1991.tb00779.x

Ittner, C. D., Larcker, D. F. (1998). Innovations in performance measurement: trends and research implications. Journal of Management Accounting Research, 10, 205-238.

Jansen, E. P. (2008). New public management: perspectives on performance and the use of performance information. Financial Accountability and Management, 24(2), 169-191. 
https://doi.org/10.1111/j.1468-0408.2008.00447.x

Johnsen, A. (2005). What does 25 years of experience tell us about the state of performance measurement in public policy and management. Public Management and Money, 25(1), 9-17. https://doi.org/10.1111/j.1467-9302.2005.00445.x

Jones, L. R., Mussari, R. (2000). Public management reform in the U.S. and Italy: accounting, measurement and financial reporting. International Public Management Review, 1(1), 56-83.

Kaplan, R. S., Norton, D. P. (1992). The balanced scorecard: measures that drive performance. Harvard Business Review, 70(1), 71-79.

Krippendorff, K. (1980). Content Analysis. An Introduction to Its Methodology. Beverly Hills, CA: Sage publications.

Kuipers, B. S., Higgs, M., Kickert, W., Tummers, L., Grandia, J., \& Van der Voet, J. (2014). The management of change in public organizations: a literature review. Public Administration, 92(1), 1-20. Htpps://doi.org/10.1111/padm.12040

Le Pogam, M., Luangsay-Catelin, J., \& Notebaert, C. (2009). La performance hospitalière: à la recherche d'un modèle multidimensionnel coherent. Revue Management et Avenir, 25, 116-134. https://doi.org/10.3917/mav.025.0116

McAdam, R., Walker, T. (2003). An inquiry into balanced scorecards within best value implementation in UK $\begin{array}{llll}\text { Local Government. } & \text { Public } & \text { Administration, } & \text { 81(4), }\end{array}$ https://doi.org/10.1111/j.0033-3298.2003.00375.x

Milne, M. J., Adler, R. W. (1999). Exploring the reliability of social and environmental disclosures content analysis. Accounting, Auditing and Accountability Journal, 12(2), 237-256. https://doi.org/10.1108/09513579910270138

Modell, S. (2009). Institutional research on performance measurement and management in the public sector accounting literature: a review and assessment. Financial Accountability and Management, 25(32), 277-303. https://doi.org/10.1111/j.1468-0408.2009.00477.x

Neely, A., Gregory, M., \& Platts, K. (1995). Performance measurement system design: a literature review and research agenda. International Journal of Operations and Production Management, 15, 80-116. https://doi.org/10.1108/01443579510083622

Patten, D. (2002). The relation between environmental performance and environmental disclosure: a research note. Accounting, Organization and Society, 27, 763-773. https://doi.org/10.1080/14486563.2011.646752

Pollitt, C., \& Bouckaert, G. (2000). Public management reform. A comparative analysis. Oxford: Oxford University Press.

Rana, T., Hoque, Z., \& Jacobs., K. (2018). Public sector reform implications for performance measurement and risk management practice: insights from Australia. Public Money and Management, Published online: 07 Feb 2018. https://doi.org/10.1080/09540962.2017.1407128

Unerman, J. (2000). Methodological issues: reflections on quantifications in corporate social reporting content analysis. Accounting, Auditing and Accountability Journal, 13(5), 667-680. https://doi.org/10.1108/09513570010353756

Van de Walle, S., (2009). International comparisons of Public Sector Performance. How to move ahead?. Public Management Review, 11(1), 39-56. https://doi.org/10.1080/14719030802493254

Van Helden, G. J., Johnsen, A., \& Vakkuri, J., (2008). Distinctive research patterns on public sector performance measurement of public administration and accounting disciplines. Public Management Review, 10(5), 641-651. https://doi.org/10.1080/14719030802264366

Yang, K., \& Holzer, M. (2006). The performance - trust link: implications for performance Measurement. Public Administration Review, 66(1), 114-126. https://doi.org/10.1111/j.1540-6210.2006.00560.x

Weber, R. P. (1985). Basic Content Analysis. Beverly Hills, CA: Sage Publications. 


\section{Copyrights}

Copyright for this article is retained by the author(s), with first publication rights granted to the journal.

This is an open-access article distributed under the terms and conditions of the Creative Commons Attribution license (http://creativecommons.org/licenses/by/4.0/). 